\title{
The ANTITRUSt Of Foreign DiRECT INVESTMENTS VIS-À-VIS ENERgY AND SUSTAINABILITY PATENTS ${ }^{a}$
}

Parham FARHANG VESAL ${ }^{\mathrm{b}}$

\footnotetext{
${ }^{\text {a }}$ This working paper is an spin-off of the author's research for his LLM thesis at the University of Lausanne, Switzerland. The author thanks Edward Kwakwa for his kind and intensive support for the preperation of the present document.

${ }^{\mathrm{b}}$ BA in English Literature; LLB (JD); MPhil in Public International Law (Tehran); LLM in International \& European Commercial Law (Lausanne); PhD Candidate in International Law and Economics (Graduate Institute Geneva).parham.farhang@graduateinstitute.ch | (+41)(78) 8895069.
} 


\section{CTEI Working Papers}

CTEI Working Papers series publishes works by Graduate Institute faculty members, students and visiting scholars.

www.graduateinstitute.ch/ctei

\section{Centre for Trade and Economic Integration (CTEI)}

The Centre for Trade and Economic Integration fosters world-class multidisciplinary scholarship aimed at developing solutions to problems facing the international trade system and economic integration more generally. It works in association with public sector and private sector actors, giving special prominence to Geneva-based International Organisations such as the WTO and UNCTAD. The Centre also bridges gaps between the scholarly and policymaking communities through outreach and training activities in Geneva.

www.graduateinstitute.ch/ctei ctei@graduateinstitute.ch 


\begin{abstract}
$\underline{\text { Abstract }}$
This study analyzes the feasibility of optimal equilibrium between antitrust exigencies and patent law necessities, when it comes to transnational investments in energy and sustainability global market. In doing so, the study first briefs on the ambits encircling the several interconnected subject-matters of law and economy associated with its general topic. Having scrutinized the current state of antitrust-patent intersection at WTO forum, the study moves on towards landmark literature and national practices and precedents regarding the interactivity of antitrust policy and patent law. With that backset, the specific antitrust problems of foreign direct investment in the global market of energy and sustainability products are explored in details. Based on all the argumentations and analyses provided, the study proposes a solution to the antitrust problem of foreign direct investment vis-à-vis energy and sustainability patents. Using mathematical schemes for decision-making, the proposed solution aims at introducing a fuzzjective efficiency test implementation for energy and sustainability patents. Lastly, the study portrays the orbits, components, and participants of a functional constitutive structure in which such decision-makings are to be carried out.
\end{abstract}





\section{TABLE OF Contents}

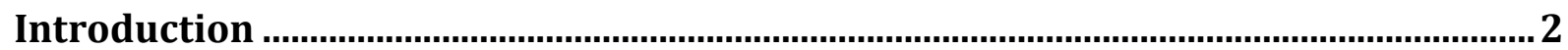

Section 1: Patent, Antitrust, and FDI Law Interactions at Transnational level ......... 5

1.1. Antitrust and Patent Intersection in WTO Framework ............................................. 6

1.1.1. Patent and Antitrust Intersection in WTO Case Law ............................. 7

a) Limited Exceptions ................................................................. 8

b) Normal Exploitation............................................................... 9

c) Legitimate Interests ..........................................................

1.1.2. The Overall of WTO Patent-Antitrust View ……................................... 11

1.2. Theories and National Practices on Patent-Antitrust.................................................. 12

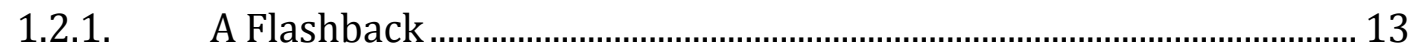

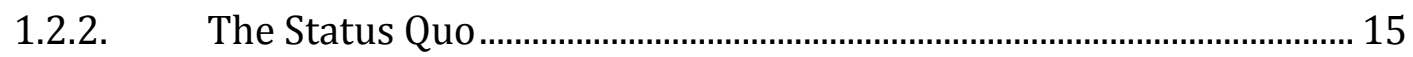

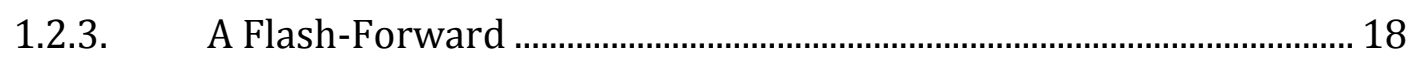

1.3. The Antitrust of FDI vis-à-vis E\&S Technologies.......................................................... 20

1.3.1. FDI and E\&S Market Structure ……......................................................... 21

1.3.2. Constitutive Gaps and Prospective Remedies ...................................... 22

Section 2: A Solution for the Future Antitrust of FDI vis-à-vis E\&S Patents ............. 24

2.1. E\&S Innovation Efficiency and the Fuzziness of Environment................................ 24

2.2. Constitutive Structure of Fuzzjective E\&S Antirust-Patent Interplay..................... 31

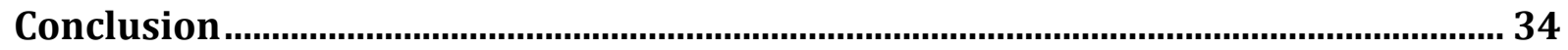




\section{Introduction}

In any developed legal system - including the umbrella of rules and orders covering the world in the name of international, transnational, or global law - both Intellectual Property (IP) law and antitrust law institutions ${ }^{3}$, form an integral part of trade and economy. The extent, to which the principles and notions of these two legal institutions are embarked upon, varies from one legal system to another. Hence, within the sphere of their availability and enforceability in a given legal system, the two institutions seek common goals in one front, and in a second front they off and on appear to clash. In this study, the focus is placed on patent (as a subject-matter of IP) and antitrust interactivity, when it comes to transnational investments in energy and sustainability (E\&S) market.

Both patent and antitrust laws are meant to enhance market efficiency and economic functionality. Yet, such an enhancement, efficiency of the market, and functionality of the economic structure, are all questions of definitions. From a patent law perspective, the social purpose of patent protection is to provide an incentive:

i. For further investment into research and development (R\&D) in order to make new inventions; and,

ii. For the patent right holder to disclose the invention. ${ }^{4}$

The antitrust policy view also signifies that "efficiency is an important social value"5 (emphasis added), hence endows to combat monopolies with the basic notions that the outcome of an aggregated competitiveness is:

i. Sustainable economic dynamism and decentralization of market mechanism6; and,

ii. Contributing to consumer welfare by maintaining allocative efficiency via the relative increase in products quality and decrease in their prices. ${ }^{7}$

This general picture of fundamental principles of patent law and those of antitrust policy depicts the area where the two institutions aim at common targets in terms of economic efficiency; yet, it is observed that:

\footnotetext{
${ }^{3}$ Infra note 33.

${ }^{4}$ Carolyn Deere-Birkbeck, "Developing Countries in the Global IP System before TRIPS: The Political Contexts of TRIPS Negotiations", in Research Handbook on the Protection of Intellectual Property under WTO Rules, (ed. Carlos M. Correa), vol. I, Edward Elgar Publishing, U.K. (2010) pp. 22-51.

5 Richard A. Posner, “Antitrust Law”, The University of Chicago Press, Second Edition (2001) p. 2.

${ }^{6}$ Lawrence A. Sullivan and Warren S. Grimes, "The Law of Antitrust: An Integrated Handbook", Second Edition, Thomson West (2006) p. 10.

7 Ibid, p. 12.
} 
“... [Conflict] can occur because of the timing of the analysis. IP analysis looks at the adequacy of innovation incentives, thus addressing the ex ante problem - the problem apparent before the innovation occurs: When incentives are inadequate. Something should be done now to increase them. This ex ante view contrasts with the ex post prospective embodied in many antitrust questions. The antitrust analysis looks at the situation that exists after the innovation is on line and asks, now that we have this technology, is it being exploited through strategies that cause undue allocative distortions?"8

The bottom line explanation for this conflict is that the monopoly conferred under patent system (and IP in general) is an exception to antitrust rule. The assumption is that the incentivization potential of patent outdoes the restraining effect of its monopolistic backlash. What remains to be an open arena of debate is the blurry spectrum where either of the two institutions "reigns supreme" ${ }^{9}$, while both play in a complementary fashion ${ }^{10}$.

One shared feature of the up-to-date patent-antitrust literature is the approach to tailor optimized schemes and solutions to fit the under study economic system as a whole - whether it be a particular national or regional economy, or the global economic order. In this study, a new sectorial sub-approach is introduced: How should antitrust and patent laws interplay when foreign direct investments (FDI) are made in the E\&S sector of transnational economy?

To that effect, there are four basic givens on the basis of which the antitrust of FDI vis-à-vis E\&S patents is analyzed within the framework of this study:

i. Patent ex ante:

With higher global protection of E\&S patents (both geographically and substantially within each competent jurisdiction) the tendency for investment inflows will increase. As a result, novel E\&S technologies are expected to be introduced at research and development (R\&D) level.

\footnotetext{
8 Ibid, p. 843.

${ }^{9}$ Louis Kaplow, "The Patent-Antitrust Intersection: A Reappraisal”, Harvard Law Review, 97:8 (1984) p. 1818.

10 Gesner Oliveira and Thomas Fujiwara, "Intellectual Property and Competition as Complementary Policies: A Test Using an Ordered Probit Model", WIPO (2007) p. 11. Available at: http://www.wipo.int/export/sites/www/ip-competition/en/studies/study ip competition oliveira.pdf (Last visited: May 12th 2015 ).
} 
ii. Patent ex post:

Those technologies that are estimated by investors to yield highest profit at lowest costs shall come into industrialization and commercialization phases. Mere efficiency of a technology is expected to be dismissed in the case that technology shall make less of a profitability promise to investors.

iii. Antitrust ex ante:

The welfare of E\&S products consumers are expected to be safeguarded and excelled, once the energy market tends to reach the threshold of perfect competition. Investments are inclined to be diverted into E\&S technologies the products of which meet the common desire of consumers in terms of both quality and price.

iv. Antitrust ex post:

With sheer antitrust policy affecting patentability of E\&S innovations or subduing the extent and extend of rights conferred to patent right holders, incentives to take up R\&D projects shall decline contrary to the patent ex ante initiatives.

It is obvious at the outset that a thoroughly authoritative and uncontrolled ${ }^{11}$ antitrust policy hits at the heart of the initial interest of innovators and investors to opt for cutting-edge E\&S technologies. It has already been concluded that "uncertainties concerning the future of energy prices and tax advantages prevent investors from committing to renewable energy projects." 12

In a situation as such, the need for a fresh air of law and policy is eminently felt to provide a breathing space of trade-off between the exigencies of requirements jointly and/or dividedly attributable to E\&S innovator, investors, and consumers. To that end, the examination of pertinent lex lata alongside the leading doctrinal propositions and

11 Infra note 67.

12 Benjamin K. Sovacool, "Placing a Glove on the Invisible Hand: How Intellectual Property Rights May Impede Innovation in Energy Research and Development (R\&D)", Albany Law Journal of Science and Technology, 18:2 (2007) p. 383; see also Benjamin Sovacool, "Why Has There Been a Relative Failure of Renewable Energy Systems in the USA?", in Renewable Energy, 24 (2006) pp. 26-27 (David Flin ed., 2006); Sudhakar Reddy and Jyoti P. Painuly, "Diffusion of Renewable Energy Technologies-Barriers and Stakeholder Perspectives", Renewable Energy, 29 (2004) pp. 1431, 1432, 1437-38, 1441, 1444-45 (discussing the results of a survey administered to energy industry representatives, policy experts, households, and businesses in India to determine barriers preventing the diffusion of solar and wind technologies); Jyoti P. Painuly, "Barriers to Renewable Energy Penetration; A Framework for Analysis", Renewable Energy, 24 (2001) pp. 73, 79-81 (discussing barriers to investment in renewable energy technologies). 
practices is the brick-and-mortar groundwork of the study, based on which further interdisciplinary schemes are devised for a de lege ferenda that aims at a feasible approach to antitrust of FDI vis-à-vis E\&S patents. At the end of the day, the ruling axiom in the present study is: salus populi suprema lex esto ${ }^{13}$.

The main notion of this study is to reemphasize the emergence of a global E\&S market for which transnational capital flow - in the form of FDI - is the pumping blood. This study acknowledges that such "emerging markets have changed the negotiating dynamics within the world trading system... [and] initiatives put forward by the developed countries at WTO and WIPO have been stalled for more than a decade as developing countries refuse to adopt them, and insist on their own agendas ${ }^{14 " 15}$. In this study, the proposition for a genuine antitrust-patent policy for FDI vis-à-vis E\&S lays not only on mere legal and mathematical techniques of substantive nature, but also casts light on a constitutive structure ${ }^{16}$ in which all participants including small and mediumsized enterprises (MSEs) and individual consumers are taken account of. ${ }^{17}$

The first section reviews the present international law of patent and antitrust and moves on to the leading scholarly writings and precedents on the issue, and subsequently demonstrates how the three legal institutions of patent, antitrust, and FDI may interplay to form the problem that is the core subject-matter of this study. In section two, a solution to the problem is proposed while employing an interdisciplinary approach that borrows from mathematical tools and literature concerning jurisprudence and political science.

\section{Section 1: Patent, Antitrust, and FDI Law Interactions at Transnational level}

In this section, effort is made to emancipate the fundamentals of substantive interrelation between patent, antitrust, and FDI taken at a transnational scale. This section is intended to exhibit two basic features of the study: the underlying intellectual

13 This is the motto of the State of Missouri in the United States of America which means: Let the welfare of the people be the supreme law (Merriam-Webster's Collegiate Dictionary).

14 The word 'agenda' is the plural form of 'agendum' in English language. The use of "agendas" here is only to remain loyal to the exact quoted text.

15 Frederick M. Abbott et al., "Emerging Markets and the World Patent Order", In Emerging Markets and the World Patent Order (Ed. Frederick M. Abbott, Carlos M. Correa, and Peter Drahos), Edward Elgar, Great Britain (2013) p. 6; See also, Susan K. Sell, "The Geo-politics of the World Patent Order", In Emerging Markets and the World Patent Order (Ed. Frederick M. Abbott, Carlos M. Correa, and Peter Drahos), Edward Elgar, Great Britain (2013) pp. 46-60; Peter Drahos, "The Global Governance of Knowledge: Patent Offices and Their Clients", Cambridge University Press, U.K. (2010).

16 Infra note 68.

17 Supra note 13 , pp. 30-31. 
engagement with the existing internationally applicable law and top-notch legal theories and practices thereto, and a view of the concrete issues that patent and antitrust policymaking in regard with transnational E\&S investments is to deal with.

The section is in three parts: first a review of how the intersections between patent and antitrust institutions are deciphered within the framework of the World Trade Organization (WTO); second, a précis on theory and national practice of global antitrust and patent intersection; third, a regard over the antitrust of FDI vis-à-vis patented E\&S state-of-the-art technologies.

\subsection{Antitrust and Patent Intersection in WTO Framework}

Within the ambit of the WTO, it is observed that the protection of IP confers a level of market power to the right holder which may consequently result in a situation of abuse de droit. With that assumption taken into consideration, the drafters of TRIPS foresaw the policy space for the countries to tackle anticompetitive conducts by means of legal measures. This policy space takes hold of the general antitrust-patent intersection and goes down into a number of technical solutions.

Assuming the general notion of antitrust-patent intersection, the Agreement provides that:

"Appropriate measures, provided that they are consistent with the provisions of this Agreement, may be needed to prevent the abuse of intellectual property rights by right holders or the resort to practices which unreasonably restrain trade or adversely affect the international transfer of technology."18 (Emphases added).

Thus, TRIPS Agreement prescribes two tests in order for the legitimacy of introducing "appropriate measures" at national level, to stop patent right holders ${ }^{19}$ from resorting to any abuse de droit application of their rights that conflicts certain issues of antitrust interest. The use of the conjunction "or" in the Article makes it possible that a positive result obtained from either of the following tests shall amount to the legitimacy of employing restrictions on patent rights:

18 TRIPS, Article 8(2).

${ }^{19}$ By referring to "patent right holders" it is intended to address any natural or legal person to whom the specific rights of a patent, or several patents bundled up in a patent pool or any other form, are directly or indirectly, jointly or severally, conferred. Such persons may be one or several patentees, licensees, successor, etc. In all the deliberations herein, once the word "patent" is mentioned, "utility model" is also mutatis mutandis intended, unless such an implicit intention is not applicable. 
i. Unreasonableness in restraining national, regional, or international trade; and,

ii. Existence of adverse effect in the international transfer of technology.

In the specific case of patents, the Agreement accepts in principle that WTO members may employ "limited exceptions" with or without an antitrust concern as the initial driving force:

"Members may provide limited exceptions to the exclusive rights conferred by a patent, provided that such exceptions do not unreasonably conflict with a normal exploitation of the patent and do not unreasonably prejudice the legitimate interests of the patent owner, taking account of the legitimate interests of third parties." 20 (Emphases added).

\subsubsection{Patent and Antitrust Intersection in WTO Case Law}

The jurisprudence of WTO Panel sheds light on the particular elements of TRIPS Agreement, Article 30. Having enumerated the triple criteria of this Article, the Panel provides a sound interpretation of this Article that is to be taken as a yardstick in case of an antitrust intersection with E\&S patents:

"Article 30 establishes three criteria that must be met in order to qualify for an exception: (1) the exception must be 'limited'; (2) the exception must not 'unreasonably conflict with normal exploitation of the patent'; (3) the exception must not 'unreasonably prejudice the legitimate interests of the patent owner, taking account of the legitimate interests of third parties'. The three conditions are cumulative, each being a separate and independent requirement that must be satisfied. Failure to comply with any one of the three conditions results in the Article 30 exception being disallowed."21

The Panel proceeds by deliberating on the interpretation of "the three conditions" expressing:

"[That] 'limited' is to be measured by the extent to which the exclusive rights of the patent owner have been curtailed... focusing on the extent to

20 TRIPS, Article 30.

${ }^{21}$ Panel Report, Canada - Patent Protection of Pharmaceutical Products, paras. 7.20-7.21. Available at: http://docsonline.wto.org/imrd/directdoc.asp?DDFDocuments/t/WT/DS/114R.DOC (Last visited: May $\left.12^{\text {th }}, 2015\right)$. 
which legal rights have been curtailed, rather than the size or extent of the economic impact."22

Yet, the necessary precaution is also employed and important stress is made where:

"The Panel does not agree, however, with the EC's position that the curtailment of legal rights can be measured by simply counting the number of legal rights impaired by an exception... To determine whether a particular exception constitutes a limited exception, the extent to which the patent owner's rights have been curtailed must be measured." 23

\section{a) Limited Exceptions}

Subsequently, the Panel stated that while economic impact was addressed, the "limited exception" condition was not related to economic concerns:

"Viewing all three conditions as a whole, it is apparent that the first condition ('limited exception') is neither designed nor intended to address the issue of economic impact directly."24

The interpretation of the phrase "do not unreasonably conflict with a normal exploitation of the patent" comes next whereas:

“The Panel considered that 'exploitation' refers to the commercial activity by which patent owners employ their exclusive patent rights to extract economic value from their patent. The term 'normal' defines the kind of commercial activity Article 30 seeks to protect... the term [normal] can be understood to refer either to an empirical conclusion about what is common within a relevant community, or to a normative standard of

22 Panel Report, Canada - Patent Protection of Pharmaceutical Products, WT/DS114/R (March 17th 2000 ) para. 7.31. Available at: http://docsonline.wto.org/imrd/directdoc.asp?DDFDocuments/t/WT/DS/114R.DOC (Last visited: May $\left.12^{\text {th }}, 2015\right)$.

${ }^{23}$ Panel Report, Canada - Patent Protection of Pharmaceutical Products, WT/DS114/R (March 17th 2000), paras. 7.32-7.33. Available at:

http://docsonline.wto.org/imrd/directdoc.asp?DDFDocuments/t/WT/DS/114R.DOC (Last visited: May $\left.12^{\text {th }}, 2015\right)$.

24 Panel Report, Canada - Patent Protection of Pharmaceutical Products, WT/DS114/R (March 17th 2000 ), para. 7.49. Available at:

http://docsonline.wto.org/imrd/directdoc.asp?DDFDocuments/t/WT/DS/114R.DOC (Last visited: May $\left.12^{\text {th }}, 2015\right)$. 
entitlement. The Panel concluded that the word 'normal' was being used in Article 30 in a sense that combined the two meanings." 25

\section{b) Normal Exploitation}

Interestingly, and close to the implications endorsed in this study in regard with DFIs in E\&S hi-techs, the Panel follows:

"The specific forms of patent exploitation are not static, of course, for to be effective exploitation must adapt to changing forms of competition due to technological development and the evolution of marketing practices. Protection of all normal exploitation practices is a key element of the policy reflected in all patent laws." 26 (Emphases added).

In the same context, the Panel found that "normal exploitation" could not simply refer back to the general concern:

“The Panel could not agree with the EC's assertion that the mere existence of the patent owner's rights to exclude was a sufficient reason, by itself, for treating all gains derived from such rights as flowing from 'normal exploitation'."27

\section{c) Legitimate Interests}

In the same case the arguments are made with respect to the term "legitimate interests" in the third condition "do not unreasonably prejudice the legitimate interests of the patent owner, taking account of the legitimate interests of third parties", and the Panel acknowledged:

"One cannot demonstrate that no legitimate interest of the patent owner has been prejudiced until one knows what claims of legitimate interest can be made. Likewise, the weight of legitimate third party interests cannot be

25 Panel Report, Canada - Patent Protection of Pharmaceutical Products, WT/DS114/R (March 17th, 2000), paras. 7.54-7.55. Available at:

http://docsonline.wto.org/imrd/directdoc.asp?DDFDocuments/t/WT/DS/114R.DOC (Last visited: May $\left.12^{\text {th }}, 2015\right)$.

26 Ibid.

27 Panel Report, Canada - Patent Protection of Pharmaceutical Products, WT/DS114/R (March 17th 2000$)$, para. 7.58. Available at: http://docsonline.wto.org/imrd/directdoc.asp?DDFDocuments/t/WT/DS/114R.DOC (Last visited: May $\left.12^{\text {th }}, 2015\right)$. 
fully appraised until the legitimacy and weight of the patent owner's legitimate interests, if any, are defined."28

The Panel addressed the claim that "legitimate interests" should be identified with legal interests:

“The word 'legitimate' is commonly defined as follows: (a) Conformable to, sanctioned or authorized by, law or principle: lawful; justifiable; proper;

(b) Normal, regular, conformable to a recognized standard type."29

And still at the vicinity of the specific interest of the present study, the Panel states:

“To make sense of the term 'legitimate interests' in this context, that term must be defined in the way that it is often used in legal discourse - as a normative claim calling for protection of interests that are 'justifiable' in the sense that they are supported by relevant public policies or other social norms... a key public policy purpose underlying patent laws is to facilitate the dissemination and advancement of technical knowledge and that allowing the patent owner to prevent experimental use during the term of the patent would frustrate part of the purpose of the requirement that the nature of the invention be disclosed to the public. To the contrary, the argument concludes, under the policy of the patent laws, both society and the scientist have a 'legitimate interest' in using the patent disclosure to support the advance of science and technology."30 (Emphases added).

Elsewhere in TRIPS Agreement, the drafters have foreseen the possibility for autonomous decision of national public authorities, without the consent of the patent right holder, to take actions against the $a b$ initio rights conferred under the relevant

28 Panel Report, Canada - Patent Protection of Pharmaceutical Products, WT/DS114/R (March 17th 2000$)$, para. 7.60. Available at:

http://docsonline.wto.org/imrd/directdoc.asp?DDFDocuments/t/WT/DS/114R.DOC (Last visited: May $\left.12^{\text {th }}, 2015\right)$.

${ }^{29}$ Panel Report, Canada - Patent Protection of Pharmaceutical Products, WT/DS114/R (March 17th 2000$)$, para. 7.68. Available at:

http://docsonline.wto.org/imrd/directdoc.asp?DDFDocuments/t/WT/DS/114R.DOC (Last visited: May $\left.12^{\text {th }}, 2015\right)$.

${ }^{30}$ Panel Report, Canada - Patent Protection of Pharmaceutical Products, WT/DS114/R (March 17th 2000$)$, para. 7.69. Available at:

http://docsonline.wto.org/imrd/directdoc.asp?DDFDocuments/t/WT/DS/114R.DOC (Last visited: May $\left.12^{\text {th }}, 2015\right)$; For a thorough analysis of Canada - Patent Protection of Pharmaceutical Products, see, Pedro Roffe and Christoph Spennemann, "Canada - Patent Protection of Pharmaceuticals", in ", in Research Handbook on the Protection of Intellectual Property under WTO Rules, (ed. Carlos M. Correa), vol. II, Edward Elgar Publishing, U.K. (2010) pp. 237-282. 
patent law regime. The case of anti-competitiveness effects on the market is also specifically mentioned in the same context:

"Where the law of a Member allows for other use of the subject matter of a patent without the authorization for the right holder, including use by the government or third parties authorized by the government, the following provisions shall be respected: ... (k) Members are not obliged to apply the conditions set forth, in subparagraphs (b) [prior request for license] and (f) [use for supply of the domestic market] above where such use is permitted to remedy a practice determined after judicial or administrative process to be anti-competitive... Competent authorities shall have the authority to refuse termination of authorization if and when the conditions which led to such authorization are likely to recur..."31 (Emphases added).

\subsubsection{The Overall of WTO Patent-Antitrust View}

The conventional law and arbitral practice of WTO portrays a controlled and orderly mechanism for states to maneuver between the two extreme poles wherein patent and antitrust institutions reign supreme. It is further indicated in explicit terms by TRIPS Agreement that "Members agree that some licensing practices or conditions pertaining to intellectual property rights which restrain competition may have adverse effects on trade and may impede the transfer and dissemination of technology."32 And also making it clear that "nothing in [the] Agreement shall prevent Members from specifying in their national legislation ... conditions that may in particular cases constitute an abuse of Intellectual property rights having an adverse effect on competition in the relevant market." 33

There are no particular case laws on the aforementioned provisions as of today, so the praxis for their interpretation remains to be the international customary law under Articles 31 and 32 of 1969 Vienna Convention on the Law of Treaties (VCLT). ${ }^{34}$ In

31 TRIPS, Article 31. There is no particular case law available in regard with this Article that might be useful to the extent that the present study requires in one way or another.

32 TRIPS, Article 41(1).

33 TRIPS, Article 41(1).

${ }^{34}$ Article 31 of VCLT: "1. A treaty shall be interpreted in good faith in accordance with the ordinary meaning to be given to the terms of the treaty in their context and in the light of its object and purpose. 2. The context for the purpose of the interpretation of a treaty shall comprise, in addition to the text, including its preamble and annexes: (a) any agreement relating to the treaty which was made between all the parties in connection with the conclusion of the treaty; (b) any instrument which was 
general, as of today, the law and practice of WTO in regard with patent-antitrust intersection remains to be superficial; yet, its mainstream direction is clear. Leaning against the text of TRIPS and the subsequent practices of WTO members and its dispute settlement body, the conclusion is derived that the policy space (at national, regional, and transnational levels) for antitrust concerns over the possible hazards of monopoly in E\&S market is open. To fill in the gaps of the WTO antitrust-patent toolkit, this study takes the benefit of delving into leading theories and national practices of global antitrust and patent intersection.

\subsection{Theories and National Practices on Patent-Antitrust}

The legal and economics literature is brimming with writings about the various dimensions of intersection between antitrust and patent institutions ${ }^{35}$. Many commentators have tried to clarify the problem in general; some in the language of economics, some by adopting the more lawyer-friendly jargon, and others have opted to employ the niceties of their preferred interdisciplinary approach trusting, inter alia, economics and legal terminologies. Nonetheless, the principal core-content of the problem is one.

In essence, the overall of the mainstream doctrine analyzes the patent rewards as the incentive for innovation, against the social costs of monopolies that antitrust law means to prevent, or at least minimize. The very same essence might be put in other words: to weigh the social value of innovations against the dis-incentivizing effects of an authoritative, yet uncontrolled ${ }^{36}$, antitrust enforcement. Respectively, in different

made by one or more parties in connection with the conclusion of the treaty and accepted by the other parties as an instrument related to the treaty. 3. There shall be taken into account, together with the context: (a) any subsequent agreement between the parties regarding the interpretation of the treaty or the application of its provisions; (b) any subsequent practice in the application of the treaty which establishes the agreement of the parties regarding its interpretation; (c) any relevant rules of international law applicable in the relations between the parties. 4 . A special meaning shall be given to a term if it is established that the parties so intended." And Article 32 of VCLT: "Recourse may be had to supplementary means of interpretation, including the preparatory work of the treaty and the circumstances of its conclusion, in order to confirm the meaning resulting from the application of article 31 , or to determine the meaning when the interpretation according to article 31: (a) leaves the meaning ambiguous or obscure; or (b) leads to a result which is manifestly absurd or unreasonable.

35 In this study "institutions are the humanly devised constraints that structure political, economic, and social interaction." See, Douglass C. North, "Institutions", Journal of Economics Perspectives, 5:1 (1991) p. 97.

${ }_{36}$ Myres S. McDougal et al., "Theories about International Law: Prologue to a Configurative Jurisprudence", Virginia Journal of International Law, 8 (1968) p. 188. 
instances of time, school, and/or jurisdiction, the result of such analyses has been the supremacy of patent over antitrust, or the reverse.

In three steps, it is tried to present the approaches towards the question of antitrust and patent intersection, the way it was (A Flashback), the way it is (The Status Quo), and the way it seems most optimum to be (A Flash-Forward).

\subsubsection{A Flashback}

In one typological assessment of the existing analyses belonging to mid-80's, the "approaches to the patent-antitrust conflict [is seen as falling] into three general categories". 37 Today, there seems to be no reason for considering this assessment as invalid and not open to refinement. To address those three categories:

i. $\quad$ Certain of the analyses "pretend in one way or another"38 that the supremacy of either of the two legal institutions (to wit, antitrust and patent) over the other is factually evident, at least within the substantive case of their examination. ${ }^{39}$

ii. In this approach the analyzer "resolves the conflict by invoking formalistic constructions that are indeterminate and only superficially address the issue". ${ }^{40}$ Although it might appear as positive at the first glance, the result of this approach is not always doomed to be void and unreliable. ${ }^{41}$

iii. To focus "on the relationship between the reward a patent receives and the value of the patent" 42 , is what the analyses of the third type are identified with. It is seen that this approach is in fact a spin-off of the first one, in the sense that it is confident with patent centrality when an antitrust unrest comes in parallel. ${ }^{43}$ This is not always the case.

\section{Supra note 7, p. 1815.}

38 Ibid.

${ }^{39}$ One may say that approaches as such are potentially (if not effectively) tantamount to the situation where half of the question is deliberately erased.

40 Supra note 7.

41 Under the negative connotations of terms such as "formalistic", "indeterminate", and "superficial" the reader viably perceives that any result obtained via the second approach is an absolute fallacy, rendered from material negligence of the analyzer. This is not correct. The quotation from Kaplow must be read in the sense that the second approach pays no significant and necessary attention to the peculiarities of each and every patent-antitrust conflict, and measures all such conflicts with the same yardstick. With this reading, it is agreeable that the second approach leaves room for the attainment of unreliable results, while its so-called yardstick fitly works in certain cases.

42 Supra note 7.

43 Supra note 7, p. 1816. 
There is a methodical misunderstanding with the perception regarding the formulation of the third approach. While the analyses of the first type are prone to, in times even haphazardly, swipe away the importance of - per chance, per person, per case, etc. - antitrust or patent notions throughout their scrutiny, in the third approach patent exigencies form the consciously defined center of gravity for the analysis. In principle, as for a third category analyzer, antitrust is the rule to which patent is an exception. This is the perception of national courts when the intersection between patent and antitrust was in its prime. ${ }^{44}$

Having put aside whether with a third approach analysis attainment of an optimally reliable result is dominantly feasible or not ${ }^{45}$, it is to be emphasized that this patentcentered approach is built on firm objective foundations. A methodical, and truly significant, difference exists between the third and the first approach, making it hard to accept the former as an offspring of the latter. Generally, the advancement of studies on the subject leaves no doubt that "the untangling of the myriad strands in the patentantitrust conflict might [not] prove impossibly difficult." 46

With all the debates on the differences and similarities between these three approaches, the leading trend in the first half of the $20^{\text {th }}$ century is to consider antitrust immunity for patent right holders. ${ }^{47}$ It is notable that the earliest of the United States judicial decisions of this type, consistently favored patent right holders' positions in their entitlement to refuse to license their patents at all. ${ }^{48}$ In a word, the flashback of patent antitrust intersection in national practice is a picture of patents reign supreme. While the status quo approach to the question has evolved substantially, decisions as such are still seen until 1980's ${ }^{49}$ :

"[Where] a patent has been lawfully acquired, subsequent conduct permissible under the patent laws cannot trigger any liability under antitrust laws."

${ }^{44}$ See, Bement v. National Harrow Co., 186 U.S. 70 (1902).

45 'Patent Misuse Doctrine' is developed in the discipline and adjudication to clarify the main defect of the patent-centered approach. See, Jere M. Webb and Lawrence A. Locke, "Intellectual Property Misuse Developments in the Misuse Doctrine", Harvard Journal of Law and Technology, 4 (1991) p. 257.

${ }^{46}$ Supra note 7.

47 See, Motion Picture Patents Co. v. Universal Film Mfg. Co., 243 U.S. 502 (1917); Bauer \& Cie v. O’Donnell, 229 U.S. 1 (1913).

${ }^{48}$ See, Henry v. A.B. Dick Co., 224 U.S. 1, 32, 35 (1912).

${ }^{49}$ SCM Corp. v. Xerox Corp., 645 F.2d 1195, 1206 (2d Cir. 1981). 


\subsubsection{The Status Quo}

The problem persists as of today, and indeed in E\&S market it is often more traceable. Although in plausible circumstances the two institutions cannot be reconciled, the premise is that patent "and antitrust can and should be complementary" 50 with the view that all the conflicts are optimally mitigated. Some studies prove "that a more frequent use and stronger enforcement of patent [institution] diminishes the probability of anticompetitive practices [and thereupon it is confirmed that patent] and antitrust are complementary, not contradictory policies." 51

One elemental factor for this complementarity criterion is the tuning of antitrust instrument with the foremost patent objective i.e. incentivization. "Antitrust restrains also tend to facilitate [industrialization] ${ }^{52}$, commercialization, and wide deployment of innovations."53 Similarly, the patent institution is to be harmonized with the tempo of premier "goals of antitrust policy"54. Conclusively, "excessive protective aspects of current [patent institution] are criticized, as is overbroad antitrust [institution] that may unnecessarily inhibit competitive uses of" 55 patent system.

In order to migrate from the patent-centered status, one argument has been on the futility of patents in terms of their unavoidable effectiveness in the creation of a meaningful incentivization for many innovations. In other words, considerable number of already patented products would have been inevitably introduced to the market, without any (or at least much of) patent rights having been conferred at the first place. Consequently, "any enhancement in the cost of a product resulting from [unjustifiable] patent protection is an allocative loss if the invention would have occurred without the patent." 56

This view corresponds with the overall economic evaluation of the consumer surplus in a price vs. quality examination, comparing the situations of perfect competition and

50 Supra note 4 , p. 841.

51 Supra note 7.

52 The general idea of industrialization in this context is borrowed from: Christopher Freeman, "Developing science, technology and innovation indicators: What we can learn from the past", Research Policy, 38:4 (2009) pp. 583-589. See, Jan Fagerberg, "Knowledge in Space: What Hope for the Poor Parts of the Globe?", In Advancing Knowledge and the Knowledge Economy, Edited by Brian Kahin and Dominique Foray, The MIT Press, Cambridge, Massachusetts (2006) pp. 217-234.

${ }^{53}$ Supra note 4, p. 843.

54 Robert H. Bork, "Antitrust and Monopoly: The Goals of Antitrust Policy", The American Economic Review, 57:2, Papers and Proceedings of the Seventy-ninth Annual Meeting of the American Economic Association (1967) pp. 242-253.

55 Supra note 4, pp. 847-848.

56 Supra note 4, p. 855. 
monopoly restrain in the market. With unjustifiable patent protection, the consumer surplus is decreased equal to the amount of the monopolist's (patentee's) profit plus the deadweight loss.

The diagram below (demand curve chart) illustrates that the "consumer surplus will increase if the price declines, or if the quality or quantity at a given price increases, or if a new and better (more valuable) alternative to the good emerges"57. By understanding the significance of this curve:

“... it is easy to see how a monopoly supplier can reduce both consumer surplus and total surplus. A monopolist will price at the point where its marginal revenue intersects with its marginal cost.

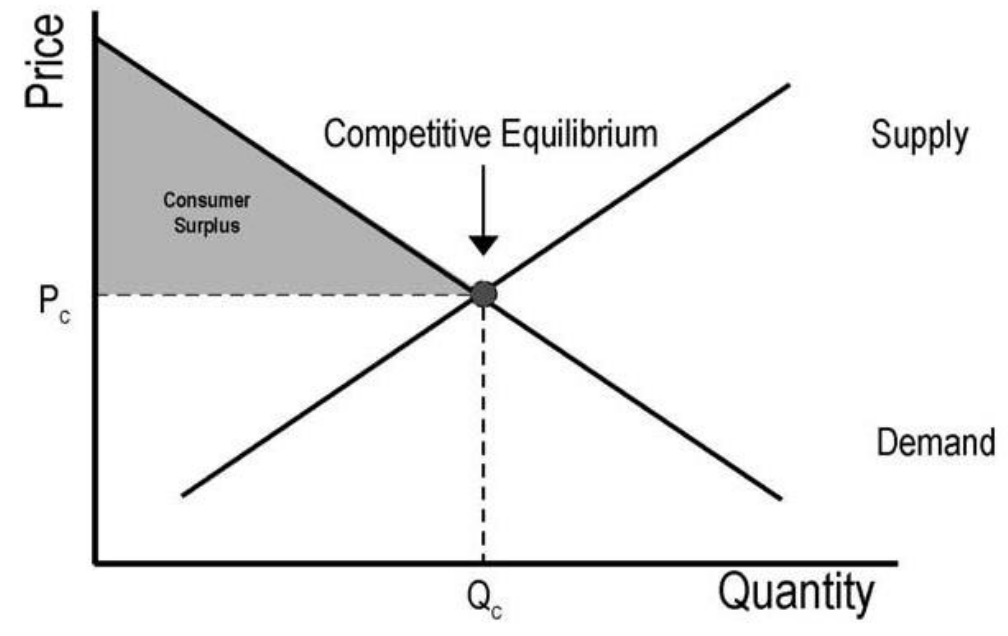

In effect... monopolist will choose to forego some additional customers in order to keep the price high. This permits the monopolist to keep a larger part of the available surplus"58.

It is further observed that the "total surplus declines because another part of the surplus simply disappears - it is a 'deadweight loss'. This is easiest to see when we add the monopolist's marginal revenue curve to the" 59 previous diagram:

57 Thomas O. Barnet, "Maximizing Welfare through Technological Innovation”, Presentation to the George Mason University Law Review 11th Annual Symposium on Antitrust, Washington DC (2007). Available at: http://www.justice.gov/atr/public/speeches/227291.htm (Last visited: May 12th, 2015).

58 Ibid.
59 Ibid. 


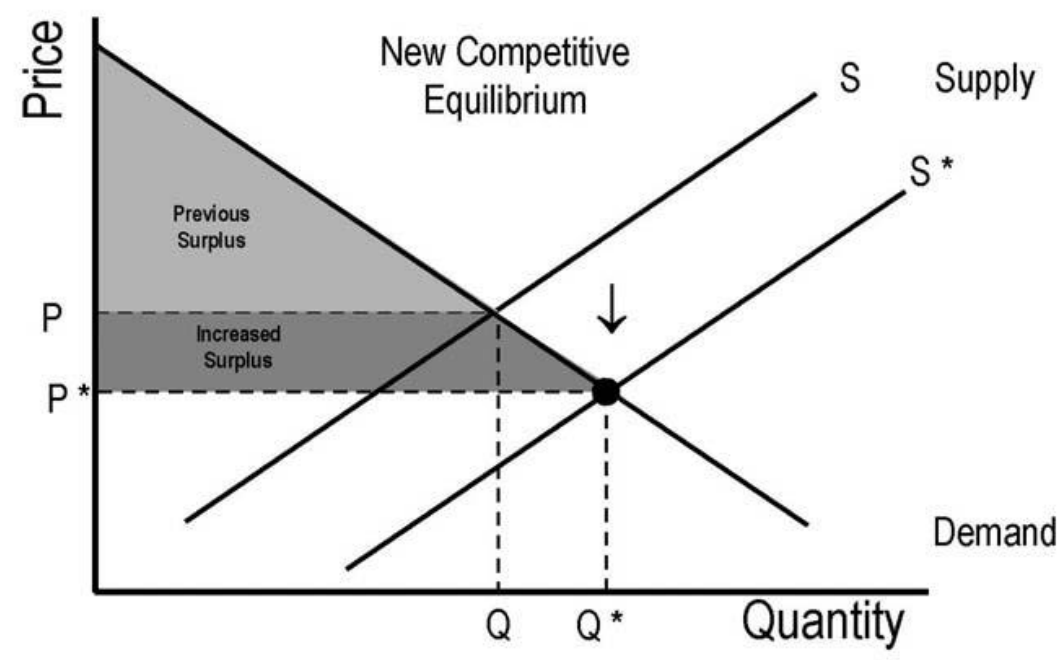

Other studies have depicted the sensitivity of cases where certain practices which are $a b$ initio legitimate e.g. sham litigation, are employed for the affirmation of entitlement to patent rights, with the final outcome of an anticompetitive character.60 Legislation of exclusive rules for the mitigation of such abuses de droit is advised by such studies. It is to be added that first of all such legislations are to be smart ${ }^{61}$, and second of all, a more important and result-oriented strategy to be adopted is norm making rather than formalistic legislation alone.

Today this is the consensus among commentators that antitrust and patent policies are to be regarded as complementary institutions and departure from an old-fashioned patent centrality is vital (with the view that the essential elements of the two institutions are to be reciprocally integrated into one another). Such an interplay-to-be ${ }^{62}$ is not a goal in itself, rather:

“... the most important problem may not concern how patent law and antitrust [interplay], but the extent to which the overall efficiency benefits from patent law could be enhanced by integrating an ex post prospective [of an antitrust nature] into the evolution of patent issues that seem

${ }^{60}$ WIPO, Committee on Development and Intellectual Property (CDIP), "Study on the AntiCompetitive Enforcement of Intellectual Property (IP) Rights: Sham Litigation", Geneva (2012). Available at: http://www.wipo.int/edocs/mdocs/mdocs/en/cdip 9/cdip 9 inf 6 rev.pdf (Last visited: May 12 $2^{\text {th }}$, 2015).

${ }^{61}$ See, Roger Adams, "The Case for Smart Legislation: The Detail Must be Flexible", paper presented to Institute for Public Policy Research (IPPR) Seminar (2002), available at: http://www.ippr.org/assets/media/uploadedFiles/projects/adamspaper.PDF(Last visited: May $12^{\text {th }}$, 2015).; Daniel L. Farkas, "Invention and Commercialization in Optical Bioimaging", Nature Biotechnology, 21 (2003) pp. 1269 - 1271, available at: http://www.nature.com/nbt/journal/v21/n11/pdf/nbt11031269.pdf (Last visited: May 12 ${ }^{\text {th }}, 2015$ ).

${ }^{62}$ This study proposes the term interplay instead of the generally accepted 'intersection', when it comes to a patent-antitrust analysis. 
debatable when examined solely from an ex ante [IP] statutory prospective."63

Should courts presume that IP rights confer market power on their owners? It takes years into the 21th century that the Supreme Court of the United States finds the opportunity to consider these questions from a novel perspective. That Court unanimously held that because Patent rights do not necessarily confer market power, courts should not presume that they $\mathrm{do}^{64}$, thus repealing some of its prior decisions. ${ }^{65}$

\subsubsection{A Flash-Forward}

If the idea of patent supremacy over antitrust is a thing of the past, then what is exactly the streamlined pattern for future? In order to give credible answer to that question, the pros of the past and present trends are to be eclectically clustered, and the cons singled out. A number of commentators (although not many) have arrayed their individual and collective talents to shed light on the future of patent-antitrust interplay (and NOT intersection). It is observed that to let patent right holders "to profit from their patents furthers the valuable social objective of encouraging innovation... [while]... enlightened intellectual property law will try to allow [them] to profit in ways that impose the smallest cost on society". 66

Some scholars (not more than a few) have bestowed their intellect to illuminate what the future law shall be. The present panorama is fed from both sources, and relies not only on the lessons from the past and present, but also on the efforts of the milestone contemporary findings. Looking at the specificities of patent-antitrust litigation at national level, it is proposed that:

"[A] settlement [of parties to the litigation, and the consequential dismissal of the case by the court] cannot lead to lower expected consumer surplus than would have arisen from ongoing litigation... Under extremely general

63 Supra note 4 , p. 858.

${ }^{64}$ See, Ill. Tool Works Inc. v. Indep. Ink, Inc. (ITW), 547 U.S. 28 (2006).

65 Some of these prior decisions include International Salt Co. v. United States, 332 U.S. 392 (1947), United States v. Loew's, Inc., 371 U.S. 38 (1962), and Jefferson Parish Hospital District No. 2 v. Hyde, 466 U.S. 2 (1984). Technically, the ITW decision deals solely with patents and relates to tying cases, not necessarily other antitrust issues. Yet, the theoretical foundation of the decision - as will become clearer to the reader - supports the notion that the decision's scope is wider than tying cases.

66 Ian Ayres and Paul Klemperer, "Limiting Patentees' Market Power without Reducing Innovation Incentives: the Perverse Benefits of Uncertainty and Non-Injunctive Remedies", Michigan Law Review, 97:4 (1999) p. 1032. 
conditions, there exists a settlement that leaves consumers better off and raises the joint profits of the [parties] engaged in the dispute."67

In a more fundamental analysis of the necessities felt for future limitation of patent rights, scholars have come to the conclusion that:

"Patents, as property rights, do not act simply as transparent conduits for market signals, but rather may introduce their own allocative distortions... the continuum of excludability shows that market-based approaches to innovation have a comparative disadvantage with respect to allocations toward highly nonexcludable [products], making it clear that patents do not act as a neutral conduit for information about social welfare." 68 (Emphasis added)

Focusing on the idiosyncrasies of E\&S market, the need is to scavenge the labyrinth of patent and antitrust interactivity, in order to configure an objective and external standpoint, to ascertain how the core-contents of the two institutions are efficiently unifiable. The main thesis behind this proposed configurative standpoint ${ }^{69}$ is bifurcated into two distinct, yet correlated, sub-theses:

i. That it is sectorial and authoritative - meaning that it is determined to fit the E\&S as a cluster of pertinent sectors in the economy, and invincibly applicable as the sole optimal solution for the problem; and,

ii. That it is dynamic and controlled - meaning that it remains to be adjustable with the fundamental change of circumstances, in a manner that legal predictability and timely enforceability endure to be uninterruptedly salient.

The last but sure not least important issue is the scope wherein the research resides. Contemplating on the subject-matter of this study in light of the specificities of an assumed transnational jurisdiction renders materially different results as compared with doing the same in an international scope. This difference is rooted in the objective variance between the constitutive structures ${ }^{70}$ and participants. This study endeavors to

${ }^{67}$ Carl Shapiro, "antitrust Limits to Patent Settlement", The RAND Journal of Economics, 34:2 (2003) p. 410.

${ }^{68}$ Amy Kapczynski and Talha Syed, "The Continuum of Excludability and the Limits of Patents", The Yale Law Review, 122:2 (2013) pp. 1962-1963.

${ }^{69}$ Michael Reisman, “The New Haven School: A Brief Introduction”, Yale Journal of International Law, 32:2 (2007) p. 575.

70 Michael Reisman, "Unilateral Actions and the Transformation of the World Constitutive Process: The Special Problem of Humanitarian Intervention", European Journal of International Law, 11:1 (2000) pp. 3-18. 
adopt a transnational approach ${ }^{71}$ for the future antitrust of FDI vis-à-vis E\&S patents, breaking away from the traditional public/private and national/international dichotomies in the study of law. ${ }^{72}$

\subsection{The Antitrust of FDI vis-à-vis E\&S Technologies}

In any given network industry ${ }^{73}$ dealing with E\&S, patents play a vital role. Day in and day out, the number of registered patents aiming at advancing the state-of-the-art via novel technicalities and/or processes are increasing, itself generating a complex system $^{74}$ the complexity of which is methodically mitigated by the introduction of business strategies such as collective patent pools. There can be feasibly a two-fold runway through which the active and potential E\&S market participants get access to patents as such:

i. R\&D (internal, outsourcing, or both); and/or,

ii. Assignment, transfer by succession, and licensing/relicensing.

In either way the aim is to industrialize (and subsequently commercialize) such patents through investment which - considering the current situation of the liberalized (and liberalizing) international economy - is more tenable to take place as FDI. This leads to the formation of a market, the two sides of which shall perform at global level:

\section{i. $\quad$ Patent right holders; and, \\ ii. Investors.}

The first question here is to examine how competitive this market is, and what are the antitrust-law-oriented concerns therein? At the end of the day, this is the consumers' right per se to have access to the optimally efficient E\&S products underpinned, and also securing the technology market efficiency that is risked to be at stake. An antitrust projection is the solution to lead investments in patented E\&S innovations, to the status of perfect competition ${ }^{75}$.

\footnotetext{
71 Supra note 7.

${ }^{72}$ Harold H. Koh et al., "Transnational Business Problems", $4^{\text {th }}$ ed., Foundation Press (2008).

${ }^{73}$ Nicolas Crettenand and Matthias Finger, "The Alignment between Institutions and Technologies in Network Industries", Competition and Regulation in Network Industries, 14:2 (2013) p. 106.

${ }^{74}$ Joel R. Paul, "The New Movements in International Economic Law", American University Journal of International Law and Policy, 10:2 (1995) p. 607.

75 George J. Stigler, "Perfect Competition, Historically Contemplated", Journal of Political Economy, 65:1 (1957) pp. 1-17; Robert Wilson, "A Bidding Model of Perfect Competition”, The Review of Economic Studies, 44:3 (1977) pp. 511-518; Mary G. Finn, "Perfect Competition and the Effects of Energy Price Increases on Economic Activity", Journal of Money, Credit and Banking, 32:3 (2000) pp. 400-416; Louis
} 


\subsubsection{FDI and E\&S Market Structure}

While the very first remedial reflection in this regard might revolve around the notion of liberalization and privatization 76 , the particular specificities of this exorbitant market require a more precisely tailored analysis. On the one hand, patents are $a b$ initio exceptions to the general rule of the first pillar of antitrust law i.e. denunciation of monopolies.

For certain reasons and under numerable conditions, the legislators in various jurisdictions - including the international arena, if therein objectively exists an institution as such - have opted to grant monopolies to those who meet the patentability criteria. Still, depending on the adopted economic/legal doctrine, the threshold and flexibility ${ }^{77}$ of such monopoly exceptions may vary on a case-by-case basis.

On the other hand, the potential investors with the required financial, expertise, and know-how backbone to meet the industrialization and commercialization necessities of such E\&S projects in a global scale, are not many in number. In antitrust jargon, any given player in this market has a sort of dominant position. This is enough to irritate the feelers of the second pillar of antitrust, namely, the censure of the abuse of market power.

The fact that these players, in order to reach their business incentives in a liberalized economy, are keen to follow concertation practices of vertical, horizontal or conglomerate nature in their relations inter se or with the patent holders, also calls for the due regard of the first antitrust pillar. Last but not least, the merger control regulations of antitrust law (third pillar) may also be activated once the monopolistic incentives of the investors are materialized through not only mergers and acquisitions mechanisms, but also formation of patent pools ${ }^{78}$.

Consequently, the type of market providing the analytical laboratory of this proposed study inherently tends to be oligopsonistic from the investors' side (if not

\footnotetext{
Makowski and Joseph M. Ostroy, "Perfect Competition and the Creativity of the Market", Journal of Economic Literature, 39:2 (2001) pp. 479-535.

76 Matthias Finger, "Limits to Privatization: How to Avoid too Much of a Good Thing", in Limits to Privatization, Earthscan, London (2005) pp. 3-14.

77 WIPO Secretariat, "Patent-Related Flexibilities in the Multilateral Legal Framework and their Legislative Implementation at the National and Regional Levels - Part III", Committee on Development and Intellectual Property (CDIP): Thirteenth Session, May 19 to May 23, 2014 (Geneva, Switzerland). Available at: http://www.wipo.int/edocs/mdocs/mdocs/en/cdip 13/cdip 13 10.pdf (Last visited: May 12th, 2015).

78 World Intellectual Property Organization (WIPO) Secretariat, "Patent Pools and Antitrust - A Comparative Analysis", March 2014. Available at: http://www.wipo.int/export/sites/www/ipcompetition/en/studies/patent pools report.pdf (Last visited: May 12 $2^{\text {th }}, 2015$ ).
} 
monopolistic due to the circumstances governing the time in a particular case), and principally monopolistic from the patent holders' side (or oligopolistic in case that there happens to be parallel patents of partial or even total resemblance in one or more than one jurisdiction all available to the globalized market).

\subsubsection{Constitutive Gaps and Prospective Remedies}

The dilemma here is that to what extent the cohesion in between such technological and economic advancements on the one hand, and the regulatory institutions there related on the other, is in optimum functionality. In the absence of an optimum cohesion in this area, the reliability and responsiveness of the whole liberalized system left with the private sector, faces major threats deteriorating both consumers' welfare and market efficiency.

Such cohesion is graspable, once the pertinent regulators/authorities are assigned with their mandates having been re-regulated and/or de-regulated ${ }^{79}$ in light of the designated co-evolution between the E\&S businesses and the institutionalized framework for FDI attributed to them. Yet, a basic challenge valid as of today is "that most countries around the world have not adopted a competition [i.e. antitrust] law. Some of these countries have embraced the principles of free market without opting to legislate for protecting competition" 80

Hypothetically there are four regulators/authorities involved: that of intellectual property (esp. patents), that of antitrust, that of E\&S, and that of FDI (which is also in charge of portfolio investments). The important point here is that as a principle any of these regulators has the capacity to act within its territorial jurisdiction; The national regulators play sovereign roles within the territorial limits of their nation-state, the supranational ones (e.g. the African Union, EU, etc.) act according to their diverse levels of competence within their respective geographical borders, and the international actors (WIPO, World Bank, WTO, etc.) although expand their effect on a universal span, are restricted to their respective statutory ambits.

It is also important to point out that currently not all such regulators exist in all jurisdictions. An effective investment regulator or an antitrust one is missing in the

\footnotetext{
${ }^{79}$ Matthias Finger et al., "The Quest for Coherence between Institutions and Technologies in Infrastructures”, Journal of Network Industries, 6:4 (2005) pp. 227-260.

${ }^{80}$ Maher M. Dabbah, "International and Comparative Competition Law", Cambridge University Press, U.K. (2010) p. 5.
} 
international level ${ }^{81}$, the intellectual property institutions in many states are relatively modest, and many regional arrangements fail to address the institutionalization of $E \& S^{82}$, antitrust, intellectual property, or even investment. In general, there is no onefor-all E\&S regulatory institutionalization pattern; energy ministries, national companies with public ownership, technical universities, ministries of higher education, regional arrangements, even government cabinet or quasi-military entities ${ }^{83}$ in some countries are vested with competences as such.

Yet, factually, the advancement of cutting-edge technologies (in many cases forming network industries) knows no political border and respects no territorial pushbacks. This point is viably crucial whereas it remains to be the biblical verse of this study that casts light on the final recommendation on the institutionalization and budgeting of substantive and/or procedural re-regulations and de-regulations to the respective stakeholders in the transnational E\&S market. Such recommendations will make it possible to concretize a predictable scheme for patent and antitrust interplay within the transnational field of investments in the global E\&S projects.

The other fundamental concern of the study is the simultaneous encapsulation of the most probable viewpoints of the affected stakeholders (investors, patent right holders, governments, etc.) that determine their behavior subsequent to the introduction of the newly regulated institutions. It is taken for granted that these stakeholders always have their non-market strategies to ease their ways into their externally regulated paths. This necessitates due attention to the results of the study as screened and perceived by all the stakeholders.

All the prospectively proposed re-regulations and de-regulations in the study have to be focused on the alignment of the FDI in the patented E\&S network industries with the relevant institutions, in light of first, the respective policies and values (in national, supranational, and international levels) and second, and at the same time, the ensuing strategies and behaviors of the stakeholders concerned. The idea is that a realistic antitrust jurisprudential perspective, comprised eclectically of the present binary

81 See, Josef Drexl et al., "More Common Ground for International Competition Law?”, Edward Elgar, U.K. (2011).

${ }^{82}$ In the EU, the Energy Charter Treaty is the guideline on this issue; a similar instrument is missing in the African Union or even NAFTA.

${ }^{83}$ In the Islamic Republic of Iran, many major E\&S projects (oil and gas, nuclear, geothermal, etc.) are handled at both policy and practice levels, by branches of, or firms affiliated to, the Revolutionary Guard. 
economic/legal scholarly theories therein, provides an optimal axiom to treat the subject at hand. ${ }^{84}$

\section{Section 2: A Solution for the Future Antitrust of FDI vis-à-vis E\&S Patents}

In the previous section, effort was made to show that a new antitrust policy for FDI vis-à-vis E\&S patents is a need, and also possible to be devised, streamlined with that current general approach to the question of patent and antitrust interplay. In this section, a solution to that question is proposed by:

i. Introducing a novel - and additional - patentability criterion for E\&S technologies;

ii. Mathematically digesting the decision-making process in the fuzzy environment of patent incentivization and market competitiveness; and,

iii. Suggesting a transnational constitutive structure for authoritative and controlled antitrust regulatory of FDI vis-à-vis E\&S patents.

The first two features of this solution is discusses in part one of this section. Subsequently, the outlines of the constitutive structure in which the first two features are meant to be concretized are presented in part two. This section intends to shed light on it proposed solution only at a first rung. Every element discussed in this section is open to tremendous elaborations of different disciplines which remain to be beyond the scope of this general study.

\subsection{E\&S Innovation Efficiency and the Fuzziness of Environment}

The current patentability requirements for E\&S technologies are no different from other types of innovations. TRIPS Agreement stipulates that:

"[Patents] shall be available for any inventions, whether products or processes, in all fields of technology, provided that they are new, involve an inventive step and are capable of industrial application... patents shall be available and patent rights enjoyable without discrimination as to the

${ }^{84}$ For general investigation of the current status of legal governance in the field of FDI and energy see, Mustafa Erkan, "International Energy Investment Law: Stability through Contractual Clauses", Wolters Kluwer, Great Britain (2011); Crina Baltag, "The Energy Charter Treaty: The Notion of Investors", Wolters Kluwer, U.K. (2012). 
place of invention, the field of technology and whether products are imported or locally produced." 85 (Emphases added).

There is no particular WTO case law on the criteria for patentability. ${ }^{86}$ Thus, the three substantive conditions of 1) being new, 2) involving an inventive step, and 3) capability of industrial application, remain to be applicable in the case of $E \& S$ technologies. ${ }^{87}$ This is considered as "the concept and purpose of TRIPS Agreement to provide a minimum standard of patentable objects." 88 What this study proposes is the implementation of a forth criterion i.e. efficiency. ${ }^{89}$ It is suggested that a given E\&S regulator shall function in parallel with the regulators vested with FDI, patent and antitrust policies, to assess the efficiency of newly introduced technologies and solutions contributing to E\&S market. The patent application that is foreseen to render more efficient technical results in terms of consumer welfare and environmental safeguards is to be provided with a more extensive threshold of protection.

In a singled-out statistical time interval (let us say one year), there happens to be an $n$ number of E\&S patent applications filed in different jurisdictions. Such applications are treated equally and according to the relevant rules and regulations to which the standard introduced by TRIPS Agreement is but a minimum. The proposition is that once the ordinary treatment of E\&S patentability is carried out, a second tier of efficiency treatment may be taken up. In the second tier, those E\&S applications that satisfy the general requirements are to be put in hierarchical order based on their degree of

85 TRIPS, Article 27(1).

${ }^{86}$ In Canada - Patent Protection of Pharmaceutical Products, WT/DS114/R (March 17th, 2000) the Panel explained its understanding of the term "without discrimination" in Article 27; See, paras. 7.94 and 7.98, at: http://docsonline.wto.org/imrd/directdoc.asp?DDFDocuments/t/WT/DS/114R.DOC (Last visited: May $\left.12^{\text {th }}, 2015\right)$. In Canada - Term of Patent Protection, WT/DS170/R (May 5th, 2000), the Panel addresses a claim of discrimination in terms of a particular "field of technology"; See, para. 7.105, at: http://docsonline.wto.org/imrd/directdoc.asp?DDFDocuments/t/WT/DS/114R.DOC (Last visited: May $\left.12^{\text {th }}, 2015\right)$. As of today, there is no specific WTO case law on the patentability criteria.

87 The Agreement explains in a footnote to Article 27(1) that "For the purposes of this Article, the terms 'inventive step' and 'capable of industrial application may be deemed by a Member to be synonymous with the terms 'non-obvious' and 'useful' respectively." Derivatives from the term novelty are also used in some national laws to the notion of being new as addressed by TRIPS Agreement.

${ }^{88}$ Peter-Tobias Stoll et al., "WTO: Trade-Related Aspects of Intellectual Property Rights", Max Planck Institute for Comparative Public Law and International Law, Martinus Nijhoff Publishers (2007) p. 471; See also, Denis Borges Barbosa, "Minimum Standards vs. harmonization in the TRIPS and Modes of Implementation at the national Level in Monist and Dualist Systems", in Research Handbook on the Protection of Intellectual Property under WTO Rules, Edward Elgar Publishing, U.K. (2010) pp. 52-109.

${ }^{89}$ For an argument on legal technicality to verify IP as lex specialis (thus being supreme over all other relevant legi generali within the legal system under study, irrespective of the adoption/enforceability time of the later - Lex specialis derogat legi generali) see, Gustavo Ghidini, "Is IP lex specialis? A Dual Test", in Intellectual Property and General Legal Principles: Is IP a Lex Specialis?, (ed. Graeme B. Dinwoodie), Edward Elgar, Great Britain (2015) pp. 91-100 . 
efficiency. The E\&S technology that renders the highest level of efficiency in terms of consumer welfare and environmental safeguards is to be placed first. Higher level of legal protection is to be allocated to the patents of higher rank in the hierarchy.

The main question is to measure if an approach as such complies with, or may derogate any of WTO rules or not. According to TRIPS Agreement:

"Members shall give effect to the provisions of this Agreement. Members may, but shall not be obliged to, implement in their law more extensive protection than is required by this Agreement, provided that such protection does not contravene the provisions of this Agreement. Members shall be free to determine the appropriate method of implementing the provisions of this Agreement within their own legal system and practice." 90 (Emphases added).

The Panel considered that the overall language of this provision cannot justify derogations from the obligations Members have, rather, with respect to its provisions on IP enforcement, the Agreement:

"[Gives] Members the freedom to implement a higher standard... [and it] does not grant Members freedom to implement a lower standard, but rather grants freedom to determine the appropriate method of implementation of the provisions to which they are required to give effect under the first sentence." 91

Of course in another proceeding, the Panel considered a claim that a WTO Member is obliged to give effect to the provisions of the TRIPS Agreement before it is able to offer more extensive protection for one particular category of IP right:

"The Panel notes that the first sentence creates an obligation for Members to give effect to the provisions of the TRIPS Agreement and the second sentence recognizes Members' freedom to implement more extensive protection, subject to a condition... a Member is obliged to give effect to the provisions of the Agreement with respect to each category of intellectual

90 TRIPS, Article 1(1).

91 Panel Report, China - Measures Affecting the Protection and Enforcement of Intellectual Property Rights, WT/DS362/R (January 26 ${ }^{\text {th }}$ 2009), para. 7.513. Available at: http://docsonline.wto.org/imrd/directdoc.asp?DDFDocuments/t/WT/DS/362R-00.doc (Last visited: May $\left.12^{\text {th }}, 2015\right)$ 
property right, irrespective of whether it implements more extensive protection in the same or another category of intellectual property right."92

The scope of members' freedom "to determine the appropriate method of implementing the provisions" is also discussed by the Panel, stating that the phrase:

“...does not grant Members freedom to implement a lower standard, but rather grants freedom to determine the appropriate method of implementation of the provisions to which they are required to give effect under the first sentence."93

It is in parallel with the same conventional approach of WTO and its arbitral subsequent practice that the arguments revolving ceiling rules have emerged. It has been suggested that in the course of time "the concept of 'minimum right' [i.e. minimum standards] has developed into a spiral of ever stronger levels of protection... to executive IP rights"94. Within that viewpoint, it is now becoming vocal that more sophisticated patent protection does exist in the WTO law itself, whereas TRIPS Agreement is seen as an instrument that "does not only create a 'floor' of minimum protection, but makes possible ceilings which place a binding maximum level on the protection of"95 patents.

Thus, the assessment of the law and jurisprudence of WTO proves that the introduction of an additional patentability criterion i.e. efficiency, for the sake of technological innovations in E\&S market, does not contravene any mandatory provisions. It is expected that with an E\&S patentability policy as such, first of all, the patent ex ante is met, and second of all, the defective influences of sheer antitrust ex post are mitigated. As a result, $R \& D$ projects of $E \& S$ shall be directed to efficiency maximization, and thereupon investments shall be made in E\&S innovations that render the highest possible standard of consumer welfare and environmental safeguard.

92 Panel Report, EC - Protection of Trademarks and Geographical Indications for Agricultural Products and Foodstuffs, WT/DS290/R (March 15th 2005$)$, para. 7.755. Available at: http://docsonline.wto.org/imrd/directdoc.asp?DDFDocuments/t/WT/DS/290R.doc (Last visited: May $\left.12^{\text {th }}, 2015\right)$.

93 Panel Report, China - Measures Affecting the Protection and Enforcement of Intellectual Property Rights, WT/DS362/R (January 26th 2009), para. 7.513. Available at: http://docsonline.wto.org/imrd/directdoc.asp?DDFDocuments/t/WT/DS/362R-00.doc (Last visited: May $\left.12^{\text {th }}, 2015\right)$.

${ }^{94}$ Annette Kur and Henning Grosse Ruse-Khan, "Enough is Enough - the Notion of Binding Ceilings in International Intellectual Property Protection", in The Regulation of Services and Intellectual Property (ed. Markus Krajewski and Bryan C. Mercurion), vol. lll, Ashgate, Uniyed Kingdom (2013) p. 477. 95 Ibid. 
The main attribute of this proposed solution is effective complementarity between antitrust and patent policies. ${ }^{96}$ It is also in line with the contemporary practices of national courts with remarkable patent-antitrust jurisprudence. ${ }^{97}$ There remains to be two questions:

i. How should an efficiency test be made among E\&S innovations to enlist a hierarchal roster of patents?

ii. Which regulator/authority and functioning within what sort of constitutive structure may take up a mandate as such?

The answer to the first question is provided by a mathematical approach. The second question is dealt with in the second part of this section. To make a hierarchical E\&S patents list, is matter of decision-making in an environment in which the goals, constraints and the consequences of possible actions are not known precisely. Such an environment is known as fuzzy by seminal works of mathematical studies on the subject. ${ }^{98}$ It is observed that:

"By decision-making in a fuzzy environment is meant a decision process in which the goals and/or constraints, but not necessarily the system under control, are fuzzy in nature. This means that the goals and/or constraints constitute classes of alternatives whose boundaries are not sharply defined." 99

To draw clear demarcation lines between E\&S patents to demonstrate their precise level of efficiency is not feasible. One E\&S innovation provides for type $x$ of efficiency, a second technology renders efficiency type $y$. In many cases, it may make no technical sense to compare heterogeneous types of E\&S efficiency indexes with one another. Thus, impreciseness is an intrinsic characteristic of an E\&S efficiency test. That very objective fact, paves the way for the validity of a fuzzy logic implementation.

In a regular patentability test (minimum standard prescribed in TRIPS Agreement), there is a positive relation between the depth and breadth of patent protection from one hand, and increase in incentivization from another hand. In general, the more the protection is available, the more is the incentive to invest in technological innovation.

96 See, Supra note 8.

97 See, Supra note 62.

98 Lotfi A. Zadeh, "Fuzzy Sets", Information and Control, 8 (1965) pp. 338-353.

${ }^{99}$ Richard E. Bellman and Lotfi A. Zadeh, "Decision-Making in a Fuzzy Environment", Management Science, 17:4 (1970) pp. B141-B164. (In the original text, article 'the' is used before the word constraints in both occasions. They are removed here, for the sake of grammatical accuracy.) 
Yet, it is argued that even in the absence of any patent protection, the incentive for innovation is not zero since moral values and personal curiosity for intellectual engagement and invention are still present.100 Also, it has been demonstrated that incentives for innovation stop to grow at some point even if patent protection is increased. ${ }^{101}$ The diagram below shows the relation between patent protection and incentivization:

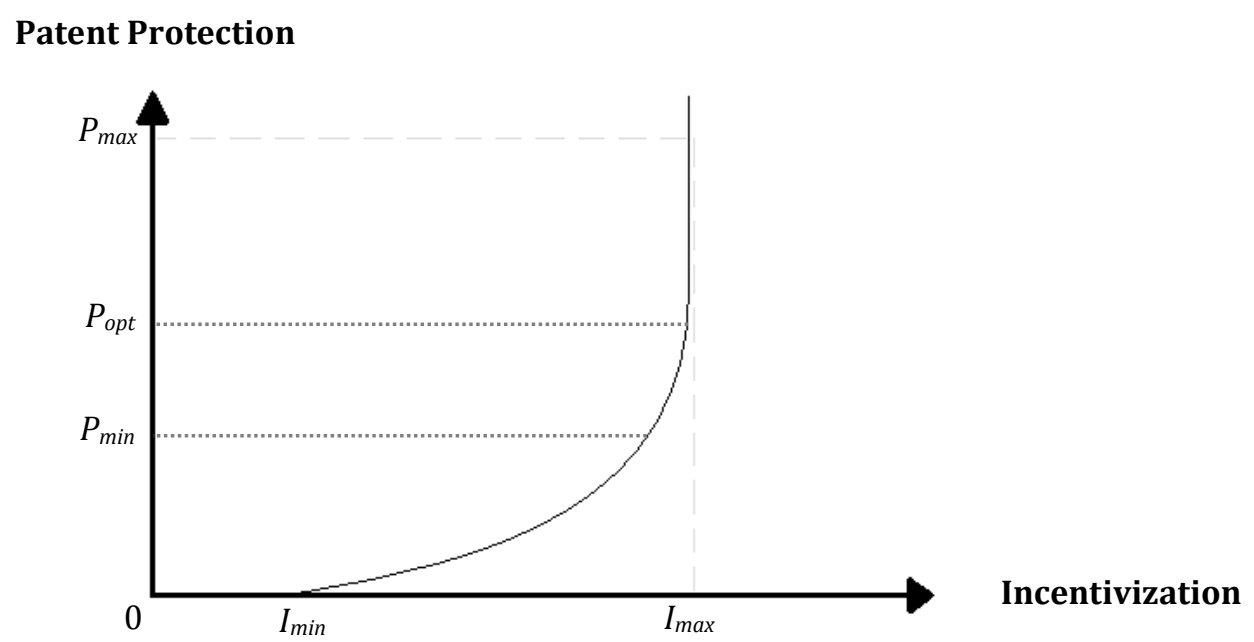

In this diagram, $P_{\max }$ is the maximum level of protection available in a given jurisdiction, $P_{\min }$ is equal to the minimum standard of protection set by TRIPS Agreement, and $P_{\text {opt }}$ is the optimum protection to be allocated to innovations where the incentives stop at their maximum $\left(I_{\max }\right) . \quad I_{\min }$ indicates the minimum level of incentivization where no patent protection is available; $I_{\min }>0$ always.

With the implementation of efficiency test in a roster of E\&S patents, the fuzziness of the environment resurfaces. In this new context, unlike the previous analysis of protection $v s$. incentivization, a patent protection scheme more sophisticated than TRIPS minimum standard (with the employment of an additional efficiency criterion) is verified against efficiency constraint. While all the E\&S patents in the list enjoy the ordinary level of protection available in the jurisdiction (which is no less than TRIPS minimum standard), the ones that stand higher in the hierarchy receive more protection.

100 Jacques De Werra, "Research Handbook on Intellectual Property Licensing", Edward Elgar Publishing (2013) pp. 93-102.

101 See, Supra Note 65. 
Let $P$ represent a set of E\&S patents, with $E(P)$ the efficiency vector of such patents. The membership in $E(P)$ is comprised of an indefinite number of efficiency level indicators $\left(E_{1}\right.$ to $\left.E_{n}\right)$ with blurry boundaries between each efficiency indicator.

$$
E(P)=\left\{E_{1}, \ldots E_{n}\right\}
$$

The diagram below demonstrates the growth in the depth and breadth of E\&S patent protection, when efficiency level is increased in a fuzzy environment over the horizontal axis. With each E\&S patent being qualified with a specific indicator by the competent regulator, the protection threshold shall be positioned on the curve.

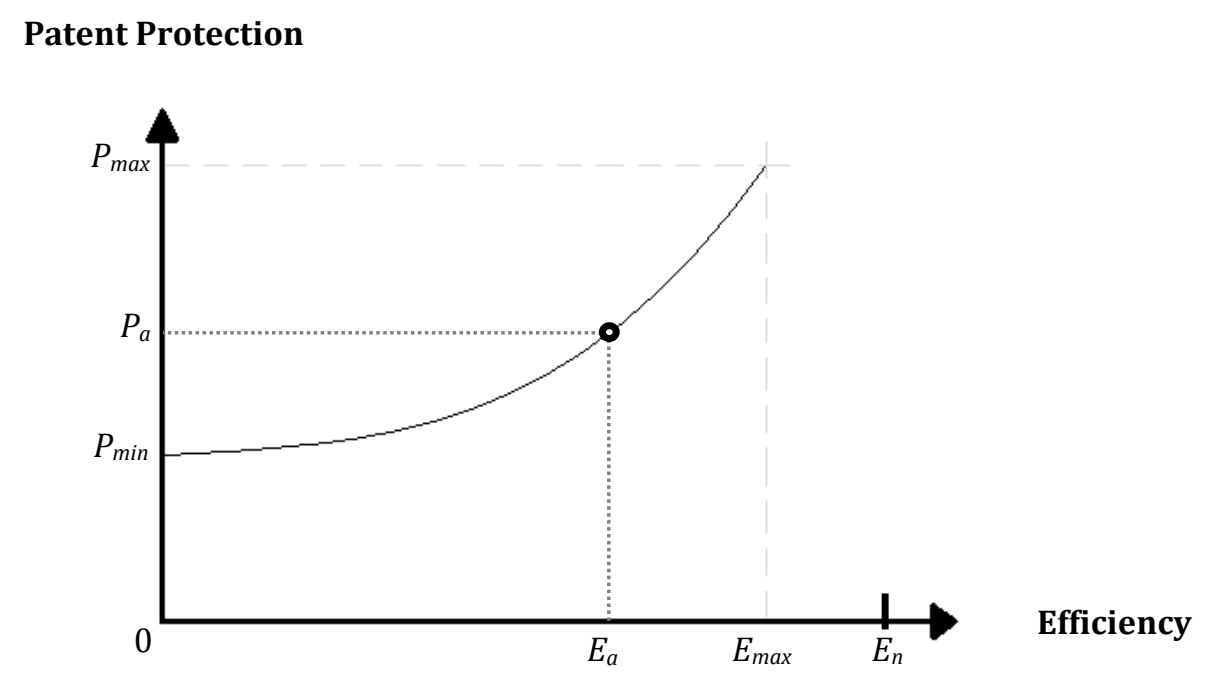

In this diagram $P_{\min }$ is the minimum protection available for patents in the jurisdiction concerned which is no less than TRIPS minimum standard. $E_{\max }$ is the maximum efficiency that the E\&S state-of-the-art presents in a certain time interval. With the R\&D advancements in E\&S market, $E_{\max }$ moves forward in the fuzzy environment of the horizontal axis to the direction of $E_{n}$. The diagram also shows an example of E\&S patent " $a$ " the efficiency indicator of which is represented by $E_{a \text {. With }}$ the assistance of the curve, the protection level of this patent $\left(P_{a}\right)$ can be allocated on the vertical axis. The limit to $P_{\max }$ is an open policy space for the competent regulator.

Although this study distinctively advises a mathematical approach to the E\&S antirust-patent interplay, it also does not negate the general statement that while "the scientific method of law-and-economics is fortified by 'mathematical models' which give the appearance of exact truth... [Yet,] those who apply these mathematical formulae 
tend to forget that these are as good as the quality of the data input, and there are virtually never measurable data in the context of legal reasoning."102 But the fact is that such negative views over the utility of mathematical methods in "law-and-economics" are basically rooted in the shallow knowledge of commentators about the tools available in mathematics as of today.

If we take the validity of this courageous claim (i.e. "there are virtually never measurable data in the context of legal reasoning") for granted ${ }^{103}$, fuzzjective ${ }^{104}$ approach to mathematics-based decision-making is itself meant to operate in an environment of impreciseness, among non-measurable "goals and/or constraints"105.

\subsection{Constitutive Structure of Fuzzjective E\&S Antirust-Patent Interplay}

In a nutshell, the proposed solution for the antitrust challenge of FDI vis-à-vis E\&S patents is a matter of decision-making in the spectrum of legal/economics policy. In this study, such decision-makings are meant to produce authoritative and controlling decisions. ${ }^{106}$ Borrowing from the New Haven School of jurisprudence, it is believed "to reserve the word 'law' for those processes of decision which are both consistent with the expectations of rightness held by members of community (authoritative decisions) and which are effective (controlling decisions)."107 Such a decision is defined as being comprised of seven functions - "In brief:

1. Intelligence is the obtaining, processing, and dissemination of information (including planning).

2. Promotion (or recommendation) is the advocacy of general policy.

3. Prescription is the crystallization of general policy in continuing authoritative community expectations.

102 Andreas Rahmatian, "A Fundamental Critique of the Law-and-Economics Analysis of Intellectual Property Rights", in Methods and Perspectives in Intellectual Property (ed. Graeme B. Dinwoodie), Edward Elgar, Great Britain (2013) p. 106.

103 Such absolutist languages that order 'never this' or 'always that' are very much prone to fallacy in the study of human sciences. As we see, this proposition is ironically a derogation of what itself tries to express as an objective fact - if "the context of legal reasoning" does not tolerate "measurable data", then how come one may feel comfortable to use a "virtually never" (and not only 'never' but "virtually never") price tag, while deliberating within the realm of that very same context?

104 For the coinage of the term 'fuzzjective' see, Vilém Novák et al., “Mathematical principles of fuzzy logic", Springer Science+Business, New York (1999).

105 Supra note 97.

106 Supra notes 34 and 67.

107 Michael Reisman, "Theory About Law: The New Haven School of Jurisprudence", Wissenschaftskolleg Jahrbuch (1989/90) p. 235 
4. Invocation is the provisional characterization of concrete circumstances in reference to prescriptions.

5. Application is the final characterization of concrete circumstances according to prescriptions.

6. Termination is the ending of a prescription and the disposition of legitimate expectations created when the prescription was in effect.

7. Appraisal is the evaluation of the manner and measure in which public policies have been put into effect and of responsibility therefor."108 (Emphases added).

The implementation of these seven functions in the fuzzy environment of efficiency test to E\&S innovations has two advantages: decisions shall become part of an integral system of FDI vis-à-vis E\&S policy, and credible precedent shall be formed to enhance future decision-making tasks of the same kind. As it can be derived from the above quotation, application of the last function (appraisal) may practically correspond to a circular performance of the seven functions anew to treat other similar tasks.

A second fundamental essence of the proposed constitutive structure is its transnationality character. Candid legal literature considers "four distinctive features" for transnational legal process:

"First, it is nontraditional: it breaks down two traditional dichotomies that have historically dominated the study of international law: between domestic and international, public and private. Second, it is non-statist: the actors in this process are not just, or even primarily, nation- states, but include non-state actors as well. Third, transnational legal process is dynamic, not static. Transnational law transforms, mutates, and percolates up and down, from the public to the private, from the domestic to the international level and back down again. Fourth and finally, it is normative. From this process of interaction, new rules of law emerge, which are interpreted, internalized, and enforced, thus beginning the process all over

108 Myres S. McDougal et al., “Theories About International Law: Prologue to a Configurative Jurisprudence", Virginia Journal of International Law, 8:2 (1968) p. 192; See, Harold D. Lasswell, "The Decision Process: Seven Categories of Functional Analysis" (College Park, Maryland: University of Maryland Press, 1956); Myres S. McDougal et al., "The World Constitutive Process of Authoritative Decisions", Journal of Legal Education, 19:3 (1967) pp. 253-300. 
again. Thus, the concept embraces not just the descriptive workings of a process, but the normativity of that process."109

These four features (nontraditional, non-statist, dynamic, and normative) shall amount to a constitutive structure in which the creation of norms (making of decisions with the expressed seven functions) is mainly taken up by the participants themselves. This means that the stakeholders of FDI and E\&S markets shall play the leading role in the creation of norms (i.e. implementation of the proposed efficiency test for E\&S patents) that shall meet antitrust requirements. While such an approach might appear contrary to the fundamental principles of public law, contemporary legal theory tries to generate a new standpoint of the issue:

"Understanding the complex interplay between law and policy requires not just asserting that international law matters, but understanding precisely how international law matters, in three key senses. First, how does transnational law function in a dynamic way to constrain state behavior over time...? A second, normative sense measures how law and legal process help to create norms and construct interests. Transnational Legal Process scholars see international norms as filtering through legal process mechanisms to play a critical role in reformulating national interests and reconstituting national interests and identities."110

With this attitude, to leave the antitrust task of FDI vis-à-vis E\&S patents' market to its non-state participants shall best serve the implementation of an additional efficiency test as proposed. It is perceived that "transnational legal process aims not simply to change behavior, but to change minds. Thus... it is the dialogic process of transnational judicial dialogue itself... that ensures the generation and proliferation of norms that are 'legitimate' on the international plane."111 Some commentators refer to a normative method as such, as "a bottom-up approach to international lawmaking"112 and bring in, inter alia, the successful example of "Berne Union and Export Credit Insurance"113.

109 Harold H. Koh, “Transnational Legal Process”, Nebraska Law Review, 75:181 (1996) p. 184.

110 Harold H. Koh, "Is there a 'New' New Haven Scholl of International Law?", Yale Journal of International Law, 32:2 (2007) p. 569.

111 Melissa A. Waters, "Normativity in the 'New' Schools: Assessing the Legitimacy of International Legal Norms Created by Domestic Courts", Yale Journal of International Law, 32:2 (2007) p. 463.

112 Janet K. Levit, "A Bottom-Up Approach to International Lawmaking: The Tale of Three Trade Finance Instruments", Yale Journal of International Law, 30:1 (2007) p. 125.

113 Ibid, p. 144. 
The final base for the materialization of the proposed constitutive structure is the selection of a right forum for the states to discuss the general policies towards a transnational antitrust of FDI vis-à-vis E\&S patents. While efforts of WTO in regard with an international competition policy have fairly reached no reckonable results, it seems to be the right time to lean against the norm creation facilities in WIPO. Deliberations on the rulemaking competences of WIPO enumerate a number of criteria that shall contribute to effective precedence. Accordingly:

“... [Such] norms would seem to be of greater precedential value if they satisfy the following criteria: (1) address matters of importance to states; (2) codify, reaffirm, or clarify certain generally accepted or widely recognized norms; (3) are adopted by consensus, by unanimity or by an overwhelming majority of the concerned member states; (4) and are adopted through a process of transparent and extensive consultation and negotiations."114

Consequently, it is proposed that the states should take up an initiative at WIPO forum, to set the bricks and mortar for a transnational constitutive structure, in which an E\&S patent efficiency test is fuzzjectively devised, and thereupon antitrust policy decisions for FDI in the transnational market of E\&S are made.

\section{Conclusion}

The implementation of a new and comprehensive antitrust policy of transnational character is a present day necessity in the global market of FDI vis-à-vis E\&S patents. Such antitrust policy decisions are to be made within the orbits of a constitutive structure administered by the global stakeholders concerned, who shall most effectively make sure for the attainment of intelligence, promotion or recommendation, prescription, invocation, application, termination, and appraisal as the seven functions of authoritative and controlling decisions. This includes the formation and application of a transnational legal process that is promised to be nontraditional, non-statist, dynamic, and normative. The substantive mandate of this constitutive structure shall be the implementation of a fuzzjective efficiency test for a roster of $\mathrm{E} \& \mathrm{~S}$ patents and make a hierarchical order thereto. In a given time interval, the $\mathrm{E} \& \mathrm{~S}$ patent that falls at the peak of hierarchy and is

114 Edward Kwakwa, "Some Comments on Rulemaking at the World Intellectual Property Organization", Duke Journal of Comparative \& International Law, 12:1 (2002) p. 192. 
foreseen to render the most efficient technical results in terms of consumer welfare and environmental safeguards, is to be provided with the most extensive threshold of protection. It is expected that with an E\&S patentability policy as such, first of all, the patent ex ante is met, and second of all, the defective influences of sheer antitrust ex post are optimally mitigated. 